\title{
The first Report of The Parasitic Copepod Bomolochus unicirrus (Copepoda: Bomolochidae) From Turkey
}

\author{
İbrahim Demirkale*, Yetkin Sakarya, Argun Akif Özak \\ Department of Fish Diseases, Faculty of Fisheries Science, Çukurova Universty, 01330 Balcall/Adana, Turkey
}

\begin{tabular}{l}
\hline A R T I C L E I N F O \\
Research Article \\
Received 11 January 2017 \\
Accepted 16 March 2017 \\
\hline
\end{tabular}

Keywords:

Bomolochus unicirrus

Turkey

Mediterranean

Parasitic copepod

SEM

* Corresponding Author:

E-mail: idemirkale@gmail.com

\begin{abstract}
A B S T R A C T
In this study, Bomolochus unicirrus Brian, 1902, a species of parasitic copepod belonging to the family Bomolochidae (Claus, 1875), was reported for the first time from the northeastern Mediterranean waters off the Turkish coast. Parasites were collected from the gill filaments of the European barracuda, Sphyraena sphyraena(L.)captured by trawling in Iskenderun Bay, Turkey. The morphological features of B. unicirrus were Redescribed and illustrated based on the newly collected material. Key diagnostic characters and newly observed details in some structures are highlighted and supported by using scanning electron microscopy (SEM). Differences and simply overlooked details in previous descriptions of $B$. unicirrus, are discussed in detail. In addition, morphological comparisons between presently reported species and the other species of the genus Bomolochus Nordmann, 1832 were also presented.
\end{abstract}

\section{Introduction}

Among the parasitic copepod families reported on both cultured and wild marine fishes so far, the Bomolochidae is one of the most species-rich taxon within the order Poecilostomatoida. In the family, the genus Bomolochus Nordmann, 1832 currently contains approximately 20 valid species (Ho and Lin, 2009). In the Mediterranean, the genus is represented by only three species, Bomolochus bellones Burmeister, 1835, Bomolochus soleae Claus, 1864, Bomolochus unicirrus Brian, 1902, reported from 9 different species of fishes belonging to, Carangidae, Clupeidae, Exocoetidae, Scomberesocidae, Soleidae, Sphyraenidae (Raibout et al 1998). Bomolochus unicirrus has been previously reported on six Mediterranean hosts by Raibaut et al (1998), (Table 1).

In this paper, we report Bomolochus unicirrusBrian, 1902 collected from the gill filament of European Barracuda, Sphyraena sphyraena (Linnaeus,1758) for the first time from the Mediterranean waters of the Turkish coast and present the scanning electron microscope images of the key diagnostic characters together with the newly observed morphological details we observed on our newly collected specimens. Slight morphological differences were noted here between this Turkish materials and materials of described from the Atlantic of Mauritania by Ho\&Rokicki (1987) and the Egyptian Mediterranean coast by El-Rashidy\&Boxshall (2012).

\section{Materials and Methods}

Parasites were collected from the inner opercular surface of the European Barracuda, Sphyraena sphyraena (L.) caught off Yumurtalik $\left(36^{\circ} 45^{\prime} 49.63^{\prime \prime N}\right.$, $\left.35^{\circ} 41^{\prime} 33.28^{\prime \prime} \mathrm{E}\right)$ in Iskenderun Bay, Turkey. Fish $(\mathrm{n}=25$; total body length range $10-23 \mathrm{~cm}$ ) were caught by otter trawl (depth range 10-20 m) during a parasitological survey conducted from June 2013 to June 2014. Parasitic copepods were immediately preserved in $70 \%$ ethanol. Subsequently, specimens were cleared in lactic acid for $2 \mathrm{~h}$ prior to examination using an Olympus SZX16 dissecting microscope and Olympus BX51 compound microscope. Specimens were dissected on glass-slides and mounted as temporary preparations in lactophenol. Measurements were made using an ocular micrometer and drawings were made with the aid of a drawing tube. All measurements were made in millimetres and are presented as the range followed by the mean in parentheses. The scientific and common names of fishes follow Froese\&Pauly(2015); the morphological terminology for the copepods follows Huys\&Boxshall(1998). The protocols for preparing crustaceans for scanning electron microscopy (SEM) outlined by Felgenhauer (1984) were followed. Ethanolfixed specimens were hydrated to distilled water and postfixed in $1-2 \%$ osmium tetroxide $\left(\mathrm{OsO}_{4}\right)$ in buffer for $2 \mathrm{~h}$, washed in distilled water, dehydrated through graded acetone series, critical point dried using liquid carbon 
dioxide as the exchange medium, mounted on aluminium stubs and sputter coated with platinum. Coated specimens were examined on a Zeiss Supra 55 (FE-SEM, Germany) field emission scanning electron microscope at $1-3 \mathrm{kV}$.

\section{Results}

Family Bomolochidae Claus, 1875

Genus Bomolochus von Nordmann, 1832

Bomolochus unicirrus Brian, 1902 (Figs. 1-4)

Host Sphyraena sphyraena (Linnaeus) (Sphyraenidae)

Host locality North-eastern Mediterranean waters off Yumurtalık in İskenderun Bay, Turkey

Site on host Gill filaments

Prevalence $16 \%$ (4 fish infected out of a total of 16 examined)

Stored1 female [NHMUK 2015.464]; 4 females are in the first author collection.

Adult female Body (Fig. 1A) 0.98-1.37 mm in length, with a mean of $1.18 \mathrm{~mm}(\mathrm{n}=7)$. Prosome $0.89-1.07 \mathrm{~mm}$ long, with a mean of $0.99 \mathrm{~mm}$, and $0.69-0.84 \mathrm{~mm}$ wide, with a mean of $0.77 \mathrm{~mm}$; comprising broad cephalothorax, and 3 free pedigerous somites; tergite on third pedigerous somite longer than second but not concealing fourth somite in dorsal view (Figs 1A, 3A,B). Urosome (Fig. 1B) $0.52-0.75 \mathrm{~mm}$ long, with a mean of $0.60 \mathrm{~mm}$, comprising fifth pedigerous somite, genital double somite and 3 free abdominal somites. All urosomal somites wider than long. First and second urosomal somite ornamented postero-ventral surface with a band of small spinules; anal somite bears two patch of spinnules on the ventral surface(Figs 1B, 3C). Caudal rami (Figs. 1B, 3B, inset) about twice as long as wide; bearing 2 long principal setae; first seta longer than second, plus 4 small setae.

Antennule (Fig. 1C) with heavily sclerotised proximal part(Fig. 3D arrowed) indistinctly 3 or 4 segmented, first segment bearing 2 plumose seta, second segment 2 plumose seta plus process (modified seta) third and fourt segment; 10 plumose seta, 6 several length selender seta on dorsal and 6 short seta on ventral surface. Distal part of antennules (Fig. 3E) 3-segmented with setal formula: 4, $2+1$ aesthetascs, $7+1$ aesthetascs.

Antenna (Figs 1D, 3F) uniramous, 3-segmented; comprising on proximal segment bearing single seta, short first endopodal segment armed with naked setaand distal segment bearing 2 small pectinate processes medially; distal armature comprising 4 curved hooks and 2 unequal setae: ventral surface of segmentand process ornamented with 7 or 8 widely-spaced rows of tiny spinules.

Mandible (Fig. 1E) bearing 2 unequal spinulate blades distally.

Maxillule (Fig. 1F, 3G) forming rounded lobe bearing 3 unequal plumose and 1 small single setae.

Maxilla (Fig. 1G) 3-segmented; proximal syncoxa long and simple seta; distal segment short and bearing small simple 2 inequal seta inersurface seta; terminal process armed with 2 accessory process plus spinulate seta.

Maxilliped (Figs 1H, 3H) comprising syncoxa armed with 1 naked seta; basis armed with 2 plumose setae; free endopodal segment incorporated into claw and bearing hirsute seta posteriorly; a sigmoid claw with a hooklet on mid-outer surface and a large hairy seta at base.

Paragnath (Fig. 1I) forming long blunt process fringed distally with short spinules.

Leg 1 (Figs 2A, 4A) biramous, modified with flattened, lamellate rami: protopod with plumose outer basal seta; protopod ornamented with patch of spinnules on ventral surface and small spine, and inner seta located distal corner. Exopod two segmented (Figs 2A, 4A) first segment with one large spine at outer distal corner; compound second segment (segments 2 and 3 fused ventrally) four small spines varied in size ornamented distal corner (Fig. 2C) and six setae. Endopod (Fig. 2B), 3 -segmented, first and second segmentseach with rows of tiny spinules on outer surface inner seta and third segment five setae.

Table 1 List of species of the genus Bomolochus Nordmann, 1832 and their fish host recorded from the Mediterrenean sea.

\begin{tabular}{l|ll}
\hline \multicolumn{1}{c|}{ Species } & \multicolumn{1}{c}{ Host } & \multicolumn{1}{c}{ References } \\
\hline $\begin{array}{l}\text { B. bellones } \\
\text { Burmeister, 1835 }\end{array}$ & $\begin{array}{l}\text { Belone belone Linnaeus, 1761 (Belonidae) } \\
\text { Tylosurus acus imperialis } \text { Rafinesque, 1810 (Belonidae) }\end{array}$ & $\begin{array}{l}\text { Papoutsoglou (1976); } \\
\text { Raibaut et al. (1998) }\end{array}$ \\
\hline B. soleae Claus, 1864 & Solea solea Linnaeus, 1758 (Soleidae) & $\begin{array}{l}\text { Radujkovic and Raibaut (1989); } \\
\text { Raibaut et al. (1998) }\end{array}$ \\
\hline & $\begin{array}{l}\text { Exocoetus } \text { volitans Linnaeus, 1758 (Exocoetidae) } \\
\text { Lichia amia Linnaeus, 1758 (Carangidae) }\end{array}$ \\
B. unicirrus Brian, & $\begin{array}{l}\text { Lichia glauca (Linnaeus, 1758) accepted as Trachinotus } \\
\text { ovatus (Linnaeus, 1758)(Carangidae) }\end{array}$ & Raibaut et al. (1998); \\
El-Rashidy and Boxshall & Sardina pilchardus Walbaum, 1792 (Clupeidae) & (2012); \\
& Scomber esoxsaurus Walbaum, 1792 (Scomberesocidae) & Brian (1902;1924) \\
& Sphyraena sphyraena Linnaeus, 1758 (Sphyraenidae) & \\
\hline
\end{tabular}

Table 2 Armature of swimming leg

\begin{tabular}{l|ccll}
\hline \multicolumn{1}{c|}{ Legs } & Coxa & Basis & Exopod & Endopod \\
\hline Leg 1 & $1-0$ & $0-1$ & I-0; IV,6 & $0-1 ; 0-1 ; 5,5$ \\
Leg 2 & $0-1$ & I-0 & I-0;I-1;III,I,5 & $0-1 ; 0-2 ;$ II,3 \\
Leg 3 & $0-1$ & I-0 & I-0; I-1; II,I,5 & $0-1 ; 0-1 ;$ II-2 \\
Leg 4 & $0-0$ & I-0 & I-0; I-1; II,I,5 & $0-$-I; 0-I; III \\
\hline
\end{tabular}




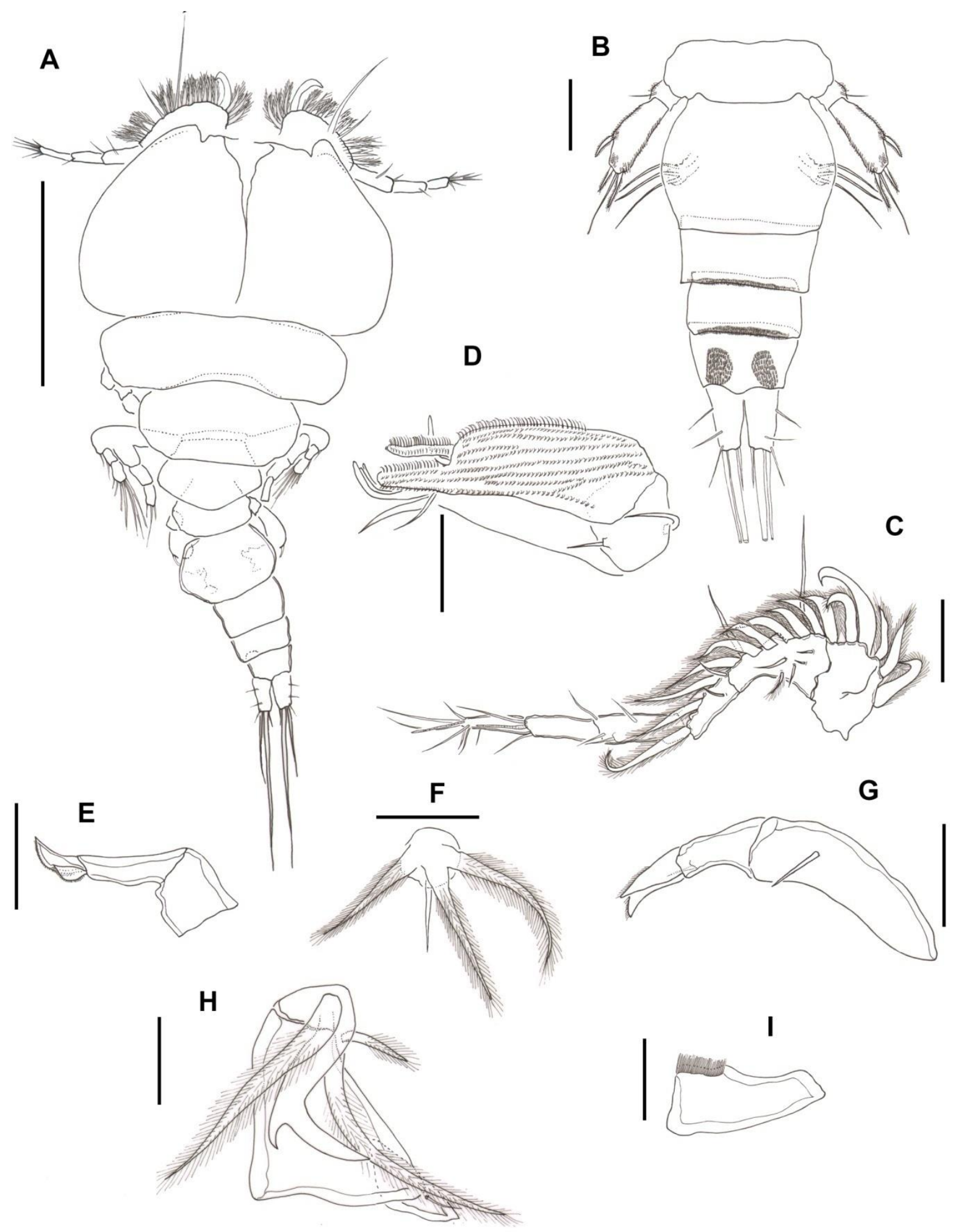

Figure 1 Bomolochus unicirrus Brian, 1902 Female. A, Habitus, dorsal view; B, Abdominal somite; C, Antennule; D, Antenna; E, Mandible; F, Maxillule; G, Maxilla; H, Maxilliped; I, Paragnath. Scale-bars: A, $500 \mu \mathrm{m} ; \mathrm{B}-\mathrm{I}, 50 \mu \mathrm{m}$; 


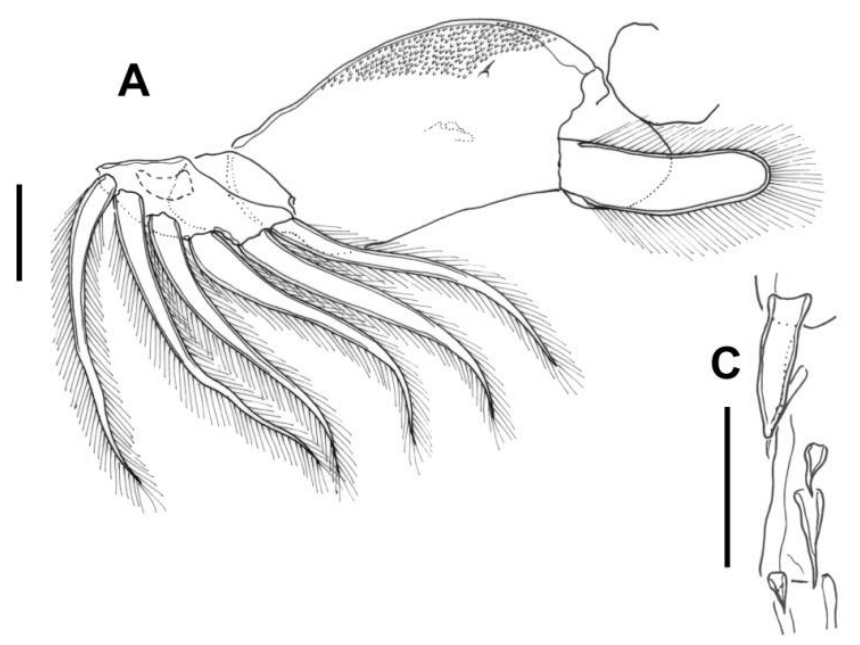

B
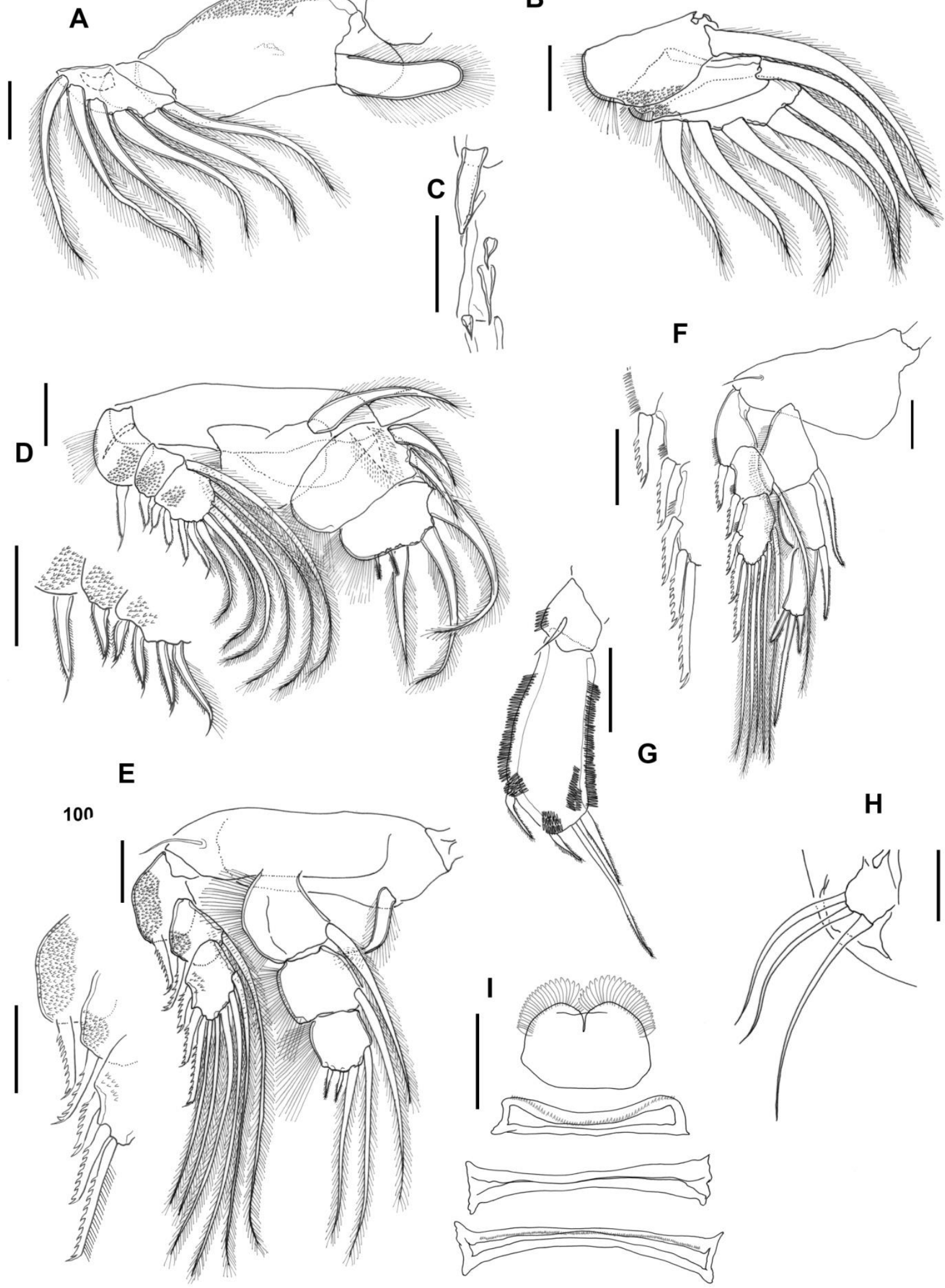

Figure 2 Bomolochus unicirrus Brian, 1902 Female. A, Leg 1Exopod; B, Leg 1 Endopod; C, Small Spines of Leg 1 Exopod; D, Leg 2; E, Leg 3; F, Leg 4; G, Leg 5; H, Leg 6; I, Interpodal sclerite of Leg 1-4. Scale-bars: A-I, 50 m. 


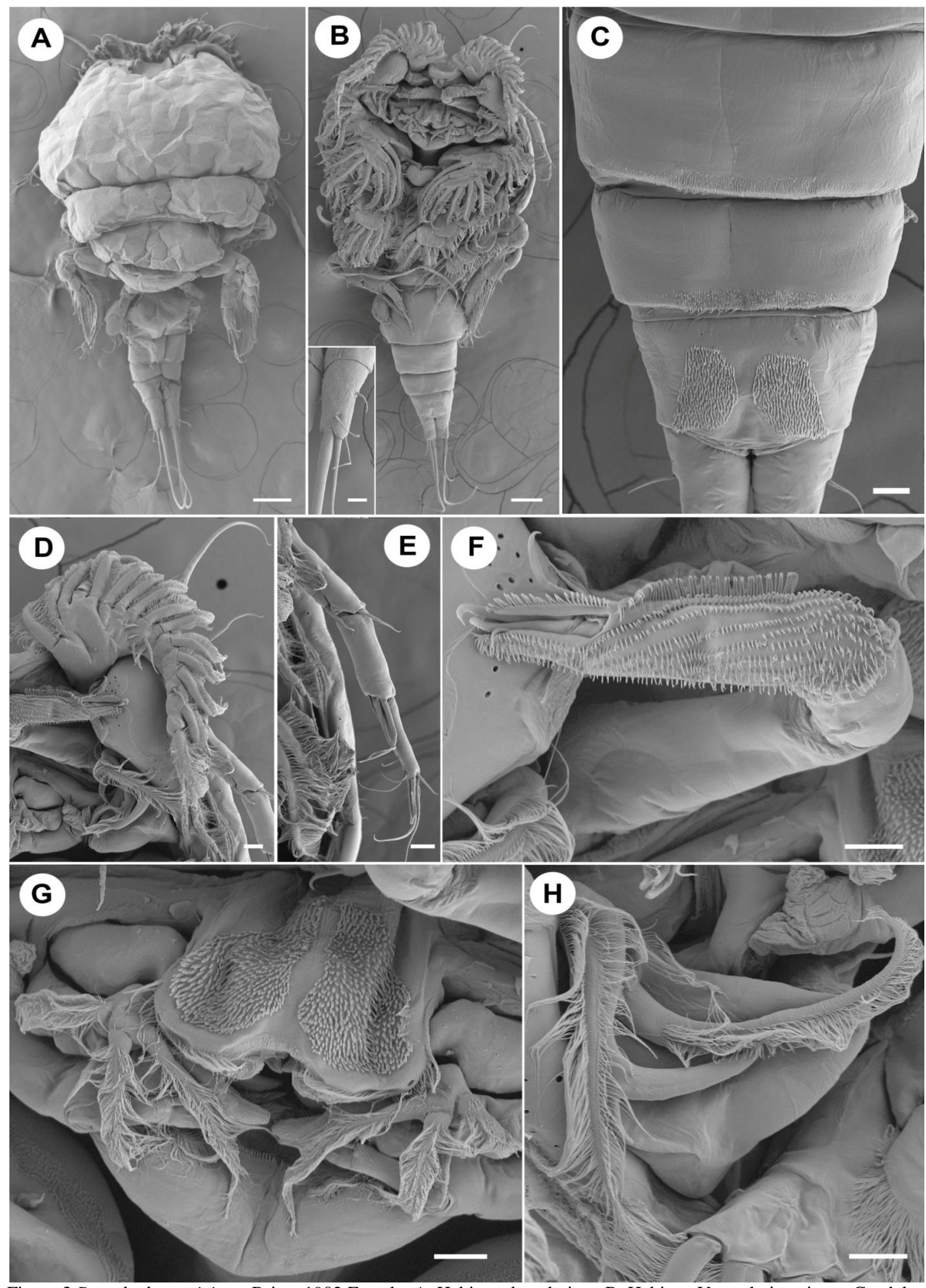

Figure 3 Bomolochus unicirrus Brian, 1902 Female. A, Habitus, dorsal view; B, Habitus, Ventral view, inset: Caudal rami; C, Urosomal somite; D, Proximal segment of Antennule; E, distal segment of Antennule; F, Antenna; G, Maxillule; H, Maxilliped. Scale-bars: A, B, 100; B inset, C-H, $20 \mu \mathrm{m}$. 

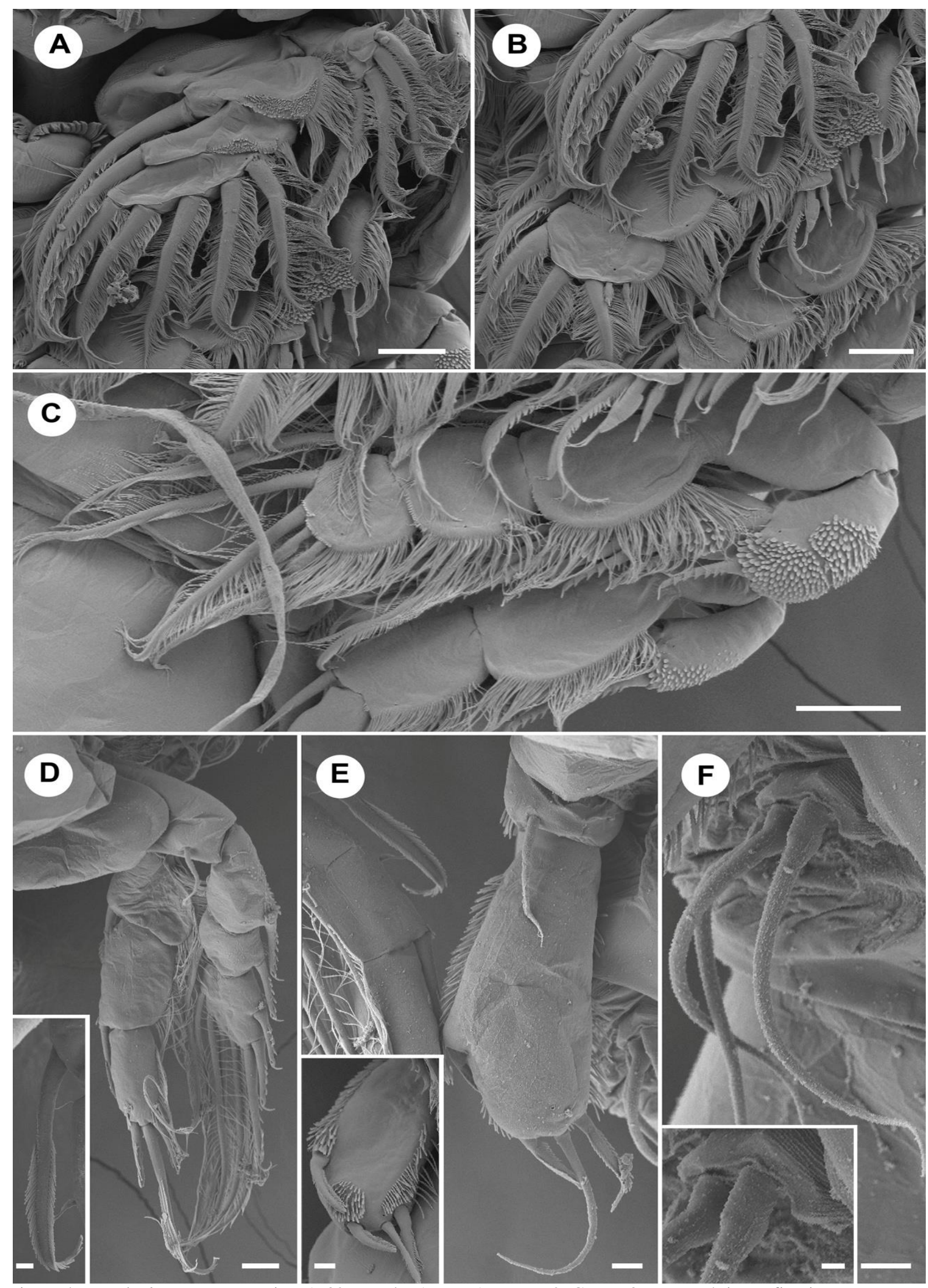

Figure 4 Bomolochus unicirrus Brian, 1902 Female. A, Leg 1; B, Leg 2; C, Leg 3; D, Leg 4, inset: first inner setae endopodal segment of leg 4; E, Leg 5, inset: ventral view; F, Leg 6, inset: sequential quite small spines. Scale-bars: AC, $50 \mu \mathrm{m} ; \mathrm{D}, 20 \mu \mathrm{m}$; D inset $2 \mu \mathrm{m}$; E, $10 \mu \mathrm{m}$, inset $10 \mu \mathrm{m} ; \mathrm{F}, 10 \mu \mathrm{m}$ : inset $3 \mu \mathrm{m}$ 
Leg 2 and 3 (Figs 2D,E, 4B,C) biramous, with 3segmented rami;outer spines on exopod bilateraly spinulate and bearing subterminal flagellum. Strong row of distal corner all exopodal segment of leg1, distal segment of exopod bearing 2 bilateral and one spinulate seta and 6 setae. Endopods 3-segmented, bearing distal membrane on surface of all inner endopodal segment and two small bilaterally ornemanted spinules and 3 plumose seta of distal segment.

Leg 4 (Figs 2F,4D) biramous, with 3-segmented rami; outher margin spines on exopod bilaterally spinulate and bearing subterminal flagellum. Ornamentation of long setules present along outer margin of all endopodal segments; coxa lacking inner seta on dorsal surface. Inner seta on first endopodal segment extending beyond articulation in origin. Inner seta on second endopodal segment extending just beyond distal margin of third. Outer apical spine on endopod tipped with flagellum about half length of inner apical spine; middle apical spine longer than second and third endopodal segments combined.

Interpodal sclerite of leg 1 with large plumose blunt process on anterior surface, leg 2 and 4 with row of small spinules but not on leg 3(Fig. 2I).

Armature of swimming leg in Table 2.

Leg 5 (Figs 2G, 4E) 2 segmented, prodopal segment small, armed with outer seta; free exopodal segment ornamented distally with tree patches of spinules, armed with subterminal seta plus 3 terminal setae, middle terminal seta naked and twice longer than others and inner setae plumose.

Leg 6 (Fig. 2H, 4F) represented by 3 long and sequential quite small spines on all setae and basis (Fig. $2 \mathrm{~F}$ inset).

\section{Remarks}

First record of Bomolochus unicirrus was given to found in the gill cavity of two Carangid fish, Lichia amia (Linnaeus, 1758) and Trachinotus ovatus (Linnaeus, 1758) (syn:L. glauca) by Richiardi (1880) without description or figures in the Mediterranean sea. In the same way, B. unicirrus was recorded but not illustrated and figured by Carus (1885) and Brian (1899). In 1902 by Brian, B. unicirrus was tried a full description based on collected from L.glauca from Italy. On the other hand Amphisile scutata (syn:Centriscus scutatus (L) has been recorded from coast of Sri Lanka. Additionally more morphological information was added fine illustrated structure of the appendages of it's which were not described by Brian (1924). The latest and best description with fine illustration of $B$. unicirrus was given on gill cavities of Lichia glauca (L) from the eastern Atlantic coast of Africa $\left(12^{\circ} 25^{\prime} \mathrm{N} 17^{\circ} 15^{\prime} \mathrm{W}\right)$ by Ho\&Rokicki (1987). Additionally they have been taken with new species Bomolochus bramus n. sp. description from the Taiwan and key to the valid species of genus Bomolochidae by Ho and Lin (2009). At the same time tree Bomolochid species; B. bellones (Burmeister, 1833), B. solea (Claus 1864), B. unicirrus (Brian 1902), were recorded in Mediterranean Sea by (Raibout et. al 1998). B. unicirrus has also been reported from Mediterranean coast of Tunusia, Egypt and Indian Ocean off Ceylon (ElRashidy and Boxshall, 2012; Benmansour and Ben Hassine, 1998; Brian, 1902). Recently these parasitic copepods was reported six host: Exocoetus volitans (Linneus, 1758), Lichia amia (Linneus, 1758), Sardina pilchardus (Walbaum, 1792), Scomberesox saurus (Walbaum, 1792), Sphyraena sphyraena (Linneus, 1758.), Trachinotus ovatus (Linnaeus, 1758) from the Mediterranean (Raibout et. al 1998).

The morphological features of our adult females were similar to those of B. unicirrus, as described by Brian (1924) and Ho and Rokicki (1987). Our comparative study also revealed that Turkish $B$. unicirrus shares the some morphological characteristic as description by Ho and Rokicki (1987). Additionally, El-Rashidy and Boxshall (2012) have discovered two different characters, hook-like modified fourth seta on the first antennulary and the length of first and second endopodal segments of leg 4 between Mauritanian and Atlantic material by Ho and Rokicki (1987). In particular, the similarities included: comprising broad cephalothorax, ornamentation and segmentation of antenna, setal formula of antennule, armature of maxilliped and segmentation and fomula of legs by Ho and Rokicki (1987) and hook-like modified fourth seta on the first antennulary and the length of first and second endopodal segments of leg 4 by El-Rashidy and Boxshall (2012). In addition we also report four previously unrecognised characters which have taxonomic value. First, there was a patch of spinules on the ventral surface of the all-abdominal segment (Fig. $1 \mathrm{~B}, 3 \mathrm{C})$; second, caudal rami without patch of spinules; third, there is row of small spinules Interpodal scleriteof leg 4 (Fig. 2I) and fourth, there are sequential small spines on all setae and basis of leg 6 (Fig. 4F).

To our knowledge, only the two species resemble to B. unicirrus with B. selaroides Pillai (1965) and B. solea Claus (1864). The first species, B. selaroides is similar with fourth (hook-like) element on basal segment of antennule protruding well beyond tip of 5 th element. However, $B$. selaroides could easily be distinguished from B. unicirrus in having ventral surface of 2nd abdominal somite smooth and outer surface of exopodal segments on legs 2-4 bearing spinules. On the other similar species, although $B$. solea have resemblance to be our material with stated by Cressey and Dojiri (1984) with patch of spinnule all abdominal segment, it can be distinguished owing to same rate of exopodal and endopodal segment of leg 4. The other recorded Bomolochid copepod species in Mediterranean Sea, $B$. bellones Burmeister, 1833, is different from B.unicirrus because of distal exopodal segment of leg 4 with 7 elements.

\section{Discussion}

European baracuda, Sphyraena sphyraena is one of the most economically important marine fish in the Mediterranean, due to its high market value. Therefore, we also compared our specimens with $B$. selaroides Pillai 1965, B. solea Claus 1864 and B. bellones Burmeister, 1833. These differences were Bomolochus bellones different from $B$. unicrrus in having exopodal segment leg 4 (8 elements), B. selaroides different from B. unicrrus in 
patch of spinnules on abdominal somite(all) and outer surface of exopodal segments on leg 2-4 bearing spinules (coarse denticle), B. solea different from B. unicrrus in rate of exopdal and endopodal segment of leg 4(endopod half times longer than exopod).

B. unicirrus could easily be distinguished from all of its congeners by a combination of characters including the number of 8 setae exopodal segment of leg 4, coarse denticle on all outer surface exopodal segment of leg 2-4, patch of spinnules on all abdominal somite and existence on caudal rami, and a half times long endopod than exopod of leg 4.

It was also has been tried to reveal the differences between different host and geografic area in this study. In future Bomolochus unicirrus, came from different hosts, it would be worth testing whether these fine morphological differences reflect corresponding molecular differences, the differences of which can be expose more indifferently.

\section{Acknowledgements}

We would like to thank Geoffrey Allan BOXSHALL (NHM, London) for advice given during writing the manuscript. We also would like to thank Prof. Süphan Karaytuğ from Mersin University, Turkey for his support during our scanning electron microscopy sessions. This research was funded by the Çukurova University Academic Research Projects Unit (Project No: FBA2016-4930).

\section{References}

Benmansour B, Ben Hassine K. 1998. Preliminary analysis of parasitic copepod species richness among coastal fishes of Tunisia, Italian Journal of Zoology, 65:S1, 341-344, DOI: 10.1080/11250009809386844

Brian A. 1899. Catalogo di Copepodi parassiti dei Pesci dell' Isola d'Elba (II. Contribuzione). Boll. Mus. Zool. Anat. Comp. Genova, no: 85 , pp. I-II

Brian A. 1902 Note su alcuni Crostacei parassiti dei pesci del Mediterraneo. Attidella Societa Ligustica di Seienze Naturali e Geofrafiche13, 1-18.
Brian A. 1924. Parasitologia Mauritanica, Materieux pour la faune parasitilogi que Mauritanie, Fascicule 1, Premiare Partie, Copepoda. Bulletin du Comited' Etudes Historiqueset Seientifiques de l'Afrique Occidentale Francaise Juille Septembre, pp.1-66.

Carus JY. 1885. Prodromus faunae mediterranae sive Descriptio Animalium maris Mediterranei incolarum quam comparata silva rarum quatenus innotuit adiectis et nominibus vulgaribus eorumque auctoribus in commodum zoologorum. I. $525 \mathrm{pp}$. Stutgart: Schwizerbart.

Cressey RF, Dojiri M. 1984. Bomolochus paucus New species Of Copepod Parasitic On Sciaenid Fishes From Southern California Usa. Proceedings of The Biological Society of Washington 97:221-225.

Felgenhauer BE. 1984. Techniques for preparing crustaceans for scanning electron microscopy. Journal of Crustacean Biology, 7, 71-76, 1984.

Froese R, Pauly D (Eds.). 2015. FishBase. World Wide Web electronic publication. www.fishbase.org [ 10 January 2015].

El-Rashidy H, Boxshall GA. 2012. Bomolochid copepods (Crustacea: Copepoda: Bomolochidae) parasitizing immigrant and native barracuda (Actinopterygii: Sphyraenidae) caught off the Egyptian Mediterranean coast. Zoosymposia 8: 20-28.

Ho J-S, Lin C-L. 2009. Bomolochus bramus n. sp. (Copepoda, Poecilostomatoida, Bomolochidae) from the pomfrets (Bramidae) off Taiwan, with a list of nominal species and key to valid species of Bomolochus von Nordmann, 1832 Zootaxa 2092: 47-57.

Ho J-S, Rokicki J. 1987. Poecilostomatoid copepods parasitic on fishes off the west coast of Africa, Journal of Natural History, 21:4, 1025-1034. DOI: 10.1080/00222938700770631.

Huys R, Boxshall GA. 1998. Copepod evolution. London: The Ray Society. 468 pp.

Radujkovic BM, Raibaut A. 1989. Parasites des poissons marins du Monténégro: copépodes. Acta Adriatica 30(1-2):237-278.

Papoutsoglou SE. 1976. Metazoan parasites of fishes from Saronicos Gulf Athens - Greece. Thalassographica, Institute of Oceanographic and Fisheries Research, Greece 1:69-89, figs. 111. (X-1976).

Raibaut A, Combes C, Benoit F. 1998. Analysis of the parasitic copepod species richness among Mediterranean fish. Journal of Marine Systems, 15, 185-206.

Richiardi S. 1880. Contribuzione alla Fauna d'Italia. I. Catalogo Sistematico dei Crostacei che Vivono sul Corpo Degli Animali Acquatici. In Catalog Degli Espositori e delle Cose Esposte, Espozitione Internazionale di Pesca in Berlino, pp. 147-152. 